\title{
The importance of vitamin D
}

\author{
Maritza Vidal Wilman ${ }^{1 *}$ and Nancy E Lane ${ }^{2}$ \\ ${ }^{1}$ Centro de Diagnóstico de Osteoporosis y Enfermedades Reumáticas (CEDOR) Lima, Perú \\ ${ }^{2}$ Center for Musculoskeletal Health, University of California at Davis School of Medicine, Sacramento, California, 95817, USA
}

\begin{abstract}
Vitamin D fulfills various functions in bone and mineral metabolism through its action on three main organs: the intestine, kidney, and bones. Calcitriol $\left[1,25-(\mathrm{OH})_{2}-\mathrm{D}_{3}\right]$ is the metabolically active form of vitamin $\mathrm{D}$ and has a high affinity for its receptor (VDR), which is expressed in most cell types. This union allows it to perform its functions at the skeletal and extra-skeletal level. Prolonged deficiency of this vitamin is mainly associated with alterations in bone mineralization and a decrease in bone mineral density leading to the subsequent development of osteomalacia and osteoporosis. This article will review the metabolism of vitamin $\mathrm{D}$, its actions at the musculoskeletal level and the consequences of the deficiency, as well as the necessary guidelines to establish the diagnosis and adequate treatment of supplementation.
\end{abstract}

\section{Introduction}

Vitamin D is fat-soluble molecule and has a structure very similar to cholesterol; it is essential in maintaining bone mass and mineral metabolism. Vitamin D acts similarly to steroid hormones, modulating the bone metabolism at a distance and directing, and interacting with other hormones. Vitamin D even acts locally as a cytokine, contributing to an immune response, cellular differentiation and proliferation suggesting the extra-skeletal effects of this hormone [1,2]. The functions of vitamin $\mathrm{D}$ on calcium and phosphorus metabolism are through its effect of three main organs: intestine, bone and kidney. There are two known forms of vitamin D: cholecalciferol (vitamin D3) of animal origin, and ergocalciferol (vitamin D2) of vegetable origin and they share the same metabolic pathways (Table 1). The 7-dehydrocholesterol (provitamin D3) is the steroid precursor in animals; and ergosterol is the precursor in plants and fungi. The 7-dehydrocholesterol forms vitamin D3 (cholecalciferol) while ergosterol becomes vitamin D2 (ergocalciferol) (Figure 1) [1,3-6].

Vitamin D can be obtained from the exposition to sunlight (which constitutes the main source in humans) or from nutritional sources of vitamin D-rich foods [2]. Vitamin D3 is synthesized in the skin from 7-dehydrocholesterol (provitamin D3), which is photolyzed into pre-vitamin D3 through exposure to ultraviolet B sunlight; and it subsequently undergoes a thermally induced transformation to vitamin D3 (cholecalciferol). Cutaneous synthesis of vitamin D is influenced by factors affecting the number of photons of ultraviolet $B$ light reaching the skin [7]. Melanin is a natural sunscreen and it effectively absorbs photons of ultraviolet B light, so that people with dark skin synthesize less vitamin $\mathrm{D}$; this is the main reason for the high incidence of vitamin D deficiency in this population (Figure 2) $[7,8]$.

Sunscreens, with sun protection factor equal to or greater than 8 , absorb between $92 \%$ and $95 \%$ of ultraviolet B photons, and significantly reduce the cutaneous synthesis of vitamin D3 [9]. Age also affects the cutaneous synthesis of vitamin $\mathrm{D}$, and it is estimated that by age 70 , the synthesis of vitamin D is only $25 \%$ of what a person of 20 years synthesizes normally [7].
Cholecalciferol is transported bound to vitamin $\mathrm{D}$ transport protein to the liver, where it undergoes a hydroxylation in position 25 , forming the 25-(OH)-D3 (calcidiol), mainly by action of several cytochrome P450 enzymes (CYP2R1, CYP27A1), named as vitamin D3-25-hydroxylase $[10,11]$. This form of vitamin $\mathrm{D}$ is inactive, but due to its stability and greater solubility in water, it represents the major circulating metabolite and vitamin D deposit [2]. The useful life of this metabolite is about $\approx 10$-19 days and the circulating calcidiol pool is in balance with that stored in adipose tissue and muscle. For all these reasons, the serum measurement of 25-(OH)-D3 reflects the status and body storage of the vitamin [12-14]. Subsequently, 25-(OH)-D3 undergoes a second hydroxylation in the proximal tubular cells of the kidney, through the action of 1- $\alpha$-hydroxylase enzyme (CYP27B1), producing the active form of vitamin D known as calcitriol: $1,25-(\mathrm{OH})_{2}-\mathrm{D}_{3}$. Hydroxylation in the liver is constitutive; while renal hydroxylation is highly regulated by different factors $[12,15]$.

Intestinal malabsorption syndromes alter the absorption of fatsoluble components such as vitamin $\mathrm{D}$; and a high proportion of vitamin $\mathrm{D}$ bound to proteins in urine is lost in nephrotic syndrome [16]. Obesity is associated with lower levels of physical activity and outdoor activities that can result in less skin synthesis of vitamin D by the sun, and vitamin D sequestration in adipose tissue [17]. Dark skin, limited sun exposure and low intake of foods fortified with vitamin $\mathrm{D}$ can all contribute to vitamin D deficiency $[16,18]$. The $1,25-(\mathrm{OH})_{2}-\mathrm{D}_{3}$ is also able to regulate its own production through inhibition of the 1-a-hydroxylase enzyme; and apparently, this is a very effective mechanism to inhibit the formation of this metabolite when there is an adequate status of vitamin D. The enzyme 1-a-hydroxylase is

${ }^{\star}$ Correspondence to: Maritza Vidal Wilman, Centro de Diagnóstico de Osteoporosis y Enfermedades Reumáticas (CEDOR) Lima-Perú, E-mail: maritzavw@gmail.com

Key words: Vitamin D, colecalciferol, calcitriol, osteoporosis, osteomalacia

Received: March 01, 2020; Accepted: March 16, 2020; Published: March 28, 2020 
also expressed in other tissues outside the kidney including the skin, intestine, brain, testicles, macrophages and placenta, which may explain some of the extra-skeletal effects of the vitamin $[19,20]$.

The major pathway for the inactivation of the vitamin D metabolites is via an additional hydroxylation through a third enzyme: CYP24A1 which degrades calcidiol and calcitriol into 24-hydroxylated products and are excreted through the bile into the feces (Figure 3) $[2,4,5,19,20]$. The $1,25-(\mathrm{OH})_{2}-\mathrm{D}_{3}$ is the main inducer of CYP24A1 promoting its inactivation and, if needed, limiting its biological effects [6,21]. The polar metabolites of $1,25-(\mathrm{OH})_{2}-\mathrm{D}_{3}$ are secreted into bile and reabsorbed via enterohepatic circulation. Modifications of this pathway, observed in patients with terminal ileum diseases, lead to accelerated

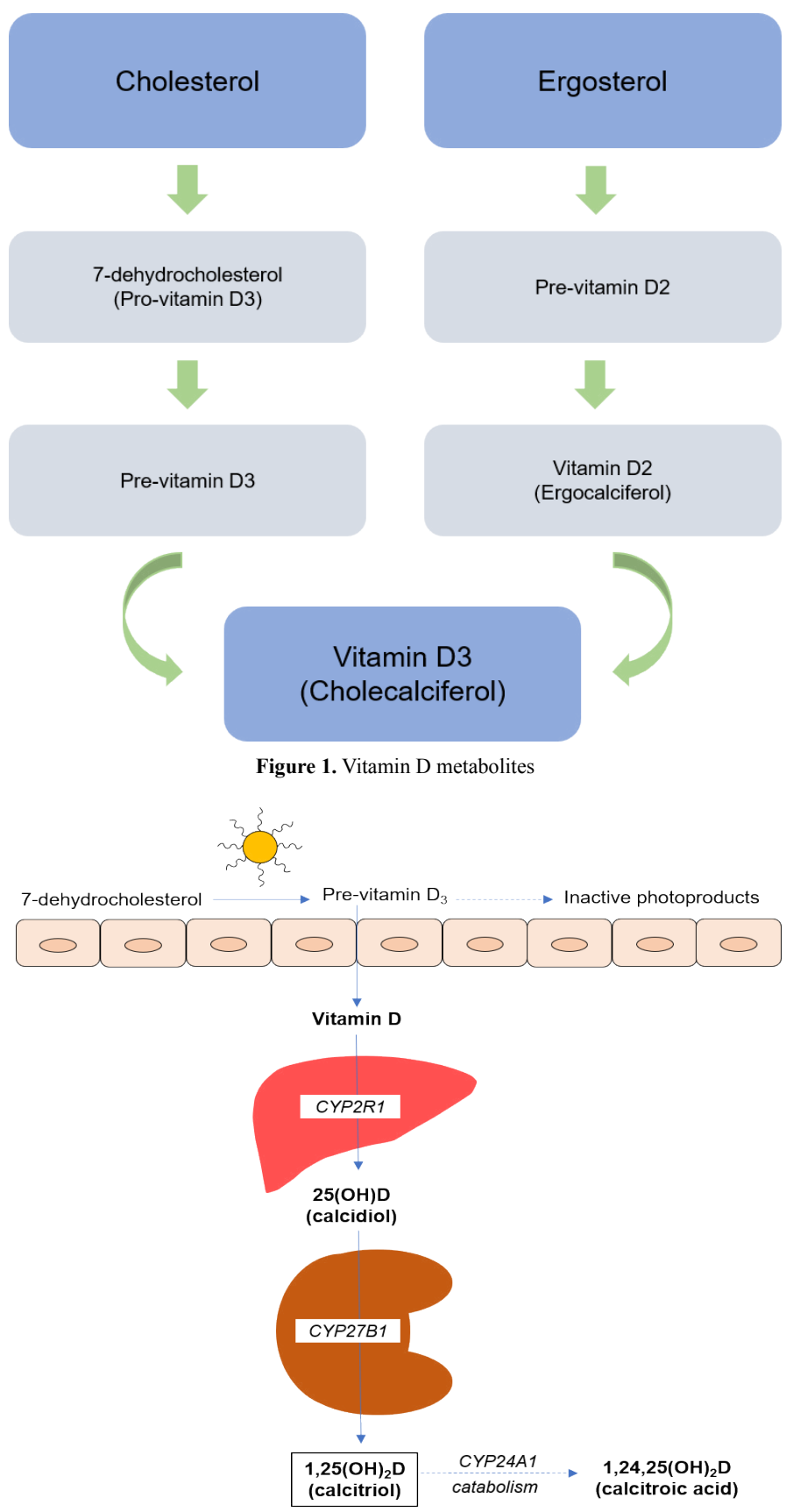

Figure 2. Vitamin D synthesis pathway. CYP2R1: 25-hydroxylase enzyme; CYP27B1: 1- $\alpha$-hydroxylase enzyme; CYP24A1: 24-hydroxylase enzyme

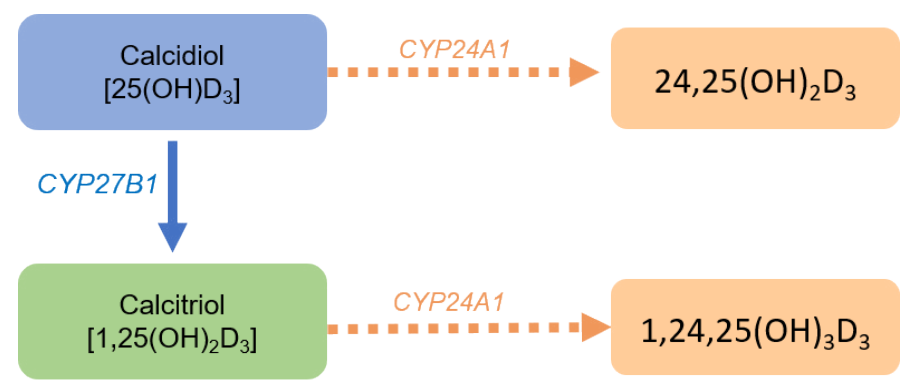

Figure 3. Formation of inactive metabolites of vitamin D. CYP27B1:1- $\alpha$-hydroxylase enzyme; CYP24A1: 24-hydroxylase enzyme

Table 1. Terms and definitions

\begin{tabular}{|l|l|}
\hline 7-dehydrocholesterol & $\begin{array}{l}\text { Chemical precursor of vitamin D3. It is converted } \\
\text { to vitamin D3 in the skin, therefore functioning as } \\
\text { provitamin-D3 }\end{array}$ \\
\hline Cholecalciferol (Vitamin D3) & $\begin{array}{l}\text { Steroid hormone produced in the skin when exposed to } \\
\text { ultraviolet light }\end{array}$ \\
\hline Ergocalciferol (Vitamin D2) & $\begin{array}{l}\text { Vitamin D of vegetable origin formed by the ultraviolet } \\
\text { irradiation of ergosterol }\end{array}$ \\
\hline Calciferol & Fat-soluble steroid, referred commonly as vitamin D \\
\hline Ergosterol & $\begin{array}{l}\text { Steroid precursor in plants and fungi that becomes } \\
\text { vitamin D2 }\end{array}$ \\
\hline $\begin{array}{l}\text { Calcidiol [25-OH-D] } \\
{[25-\mathrm{OH}-\mathrm{D} 3] \text { if animal origin }} \\
{[25-\mathrm{OH}-\mathrm{D} 2] \text { if vegetable origin }}\end{array}$ & $\begin{array}{l}\text { Hepatic metabolite produced after the first } \\
\text { hydroxylation of cholecalciferol in the liver. }\end{array}$ \\
\hline $\begin{array}{l}\text { Calcitriol [1,25-(OH) }-\mathrm{D}] \\
{\left[1,25-(\mathrm{OH})_{2}-\mathrm{D}_{3}\right] \text { if animal origin }} \\
{\left[1,25-(\mathrm{OH})_{2}-\mathrm{D}_{2}\right] \text { if vegetable origin }}\end{array}$ & Active form of vitamin D \\
\hline 25-hydroxylase enzyme & $\begin{array}{l}\text { CYP2R1, hepatic enzyme in charge of hydroxylation of } \\
\text { cholecalciferol into calcidiol }\end{array}$ \\
\hline $1-\alpha$-hydroxylase enzyme & $\begin{array}{l}\text { CYP27B1, renal enzyme in charge of hydroxylation of } \\
\text { calcidiol into calcitriol }\end{array}$ \\
\hline $\begin{array}{l}\text { 25-(OH)-D-24- } \alpha \text {-hydroxylase } \\
\text { 24-hydroxylase } \\
1,25-(\mathrm{OH})_{2-} \text { D-24-hydroxylase }\end{array}$ & $\begin{array}{l}\text { CYP24A1, oxidation enzyme that catabolizes } \\
\text { metabolites of vitamin D into soluble calcitroic acid for } \\
\text { rapid renal excretion }\end{array}$ \\
\hline Calcitroic acid & $\begin{array}{l}\text { Inactive product result of the catabolism of calcitriol, it } \\
\text { is soluble in water and excreted in bile }\end{array}$ \\
\hline
\end{tabular}

loss of vitamin D metabolites [19]. In the kidney, 1-a-hydroxylase enzyme is induced by PTH, hypocalcemia and hypophosphatemia in order to form a greater amount of $1,25-(\mathrm{OH})_{2}-\mathrm{D}_{3}[6,22]$.

The biological activity of the $1,25-(\mathrm{OH})_{2}-\mathrm{D}_{3}$ is mediated by its high affinity to nuclear vitamin $\mathrm{D}$ receptor (VDR), which acts as a transcriptional factor activated by ligand [23]. The VDR was originally found in tissues involved in calcium metabolism such as bone, intestine, kidney and parathyroid gland, but it is known that its distribution is wider, which helps to explain the additional actions attributed to this hormone [19,21].

Vitamin D3 (cholecalciferol) and vitamin D2 (ergocholesterol) are fat-soluble vitamins, and when ingested are absorbed in the small bowel in presence of bile salts incorporated into chylomicrons and transported in the circulation bound to plasma proteins (mainly vitamin D binding protein) [19,24-27]. Finally, they follow the same metabolic pathways and enzymatic transformations above described $[19,20]$. Both forms of vitamin $\mathrm{D}$ have qualitatively similar biologic actions and they are stored in fat cells. Plasmatic concentration of $1,25-(\mathrm{OH})_{2}-\mathrm{D}_{3}$ is 1000 times lower than 25-(OH)-D and has a half-life of 3-6 hours. In addition, levels of $1,25-(\mathrm{OH})_{2}-\mathrm{D}_{3}$ can be found normal or even elevated in people with vitamin $\mathrm{D}$ deficiency due to secondary hyperparathyroidism $[27,28]$.

In the intestine, vitamin $\mathrm{D}$ improves the absorption of calcium and phosphorus by increasing the expression of the epithelial channels 
of intestinal calcium $[19,24]$ and upregulation of calbindin D9K, a calcium binding protein which is expressed in the intestine and plays an important role of active transport of calcium through the enterocyte $[19,21,24]$. In bone, vitamin D has effects on bone turnover, it can increase bone resorption in order to maintain calcium homeostasis; but it also plays an important role in the mineralization of the bone matrix and in the development of proper bone mass [19,29]. Vitamin $\mathrm{D}$ can induce bone resorption through the molecular mechanism of the receptor activator for nuclear factor $\kappa B$ ligand (RANKL) [30], osteoblasts have receptors (VDR) that recognize $1,25-(\mathrm{OH})_{2}-\mathrm{D}_{3}$ and thus increase the expression of RANKL in its membrane [20,31,32]. The osteoclastic progenitor cells have receptors (RANK) that bind to RANKL, inducing its maturation and activity [20,31,32]. Vitamin $\mathrm{D}$ effects in bone can depend on the state of the calcium balance, in hypocalcemia it might increase osteoclastogenesis to restore the normal calcium balance [20].

When calcium obtained from the diet is insufficient to maintain normal serum levels of this mineral, reduced levels of ionized calcium is recognized by the calcium sensor in the parathyroid gland and the production and release of $\mathrm{PTH}$ is increased. PTH promotes renal production of $1,25-(\mathrm{OH})_{2}-\mathrm{D}_{3}$ and it also promotes renal calcium reabsorption [33]. Moreover, $\mathrm{PTH}$ interacts with the osteoblastic PTH-1 receptor and the $1,25-(\mathrm{OH})_{2}-\mathrm{D}_{3}$ interacts with its receptor in osteoblasts $[20,34]$ resulting in an increased expression of RANKL, which by interacting with its RANK receptor in the pre-osteoclast, initiates the transformation and maturation from pre-osteoclasts to mature osteoclasts enhancing the bone resorption to maintain acceptable calcium levels in blood. Likewise, vitamin D regulates transcription, differentiation and maturation of osteoblasts; and it increases the synthesis of collagen and other bone matrix proteins $[27,35,36]$. For normal mineralization, a balance between the levels of inorganic phosphate $(\mathrm{Pi})$ and extracellular inorganic pyrophosphate $(\mathrm{PPi})$ is required. This process is regulated by the PTH $-1,25-(\mathrm{OH})_{2}-\mathrm{D}_{3}$ axis, and by other local and systemic factors [37]. The degree of bone mineralization is an important determinant of bone strength and fracture toughness [38]. Moreover, vitamin D is involved in the conservation of bone microarchitecture and strength [39,40].

Vitamin D exerts other actions on the human musculoskeletal system, which supports the transport of calcium in the muscle, the growth of muscle cells and the synthesis of proteins necessary for good muscle function [19,41]. This action is mediated by genomic (through VDR receptor) and non-genomic pathways. The muscle strength in the quadriceps, grip strength and muscle function in the lower limbs is positively correlated to serum $25-(\mathrm{OH})-\mathrm{D}[42,43]$. The beneficial actions of vitamin $\mathrm{D}$ on muscle include a reduction in the risk of falls and fractures. Ninety percent of non-vertebral fractures related to osteoporosis are associated with low impact falls; and vitamin D supplement reduced by $49 \%$ the risk of further falls, contributing significantly to reduce the risk of fractures [41]. Bischoff-Ferrari conducted a meta-analysis and found $22 \%$ reduction in falls (corrected OR, $0.78,95 \%$ confidence interval [CI], 0.64-0.92) compared to patients who received calcium or placebo. The investigators concluded supplementing vitamin D might reduce the risk of falls among older people [44]. Another meta-analysis evaluated 26 clinical studies with a total of 45,782 enrolled patients. The administration of vitamin $D$ reduced the risk of falls, especially in those who had a deficiency of vitamin D by administering with calcium supplementation (OR for suffering at least one fall, $0.86,95 \%$ confidence interval, $0.77-0.96$ ). However, the quality of the evidence was low in this study [45]. Conversely, a randomized controlled study evaluated the annual administration of a high dose of vitamin D (500,000 IU of cholecalciferol) orally in older women versus the administration of placebo. The study found that 171 patients suffered fractures in the vitamin D group versus 135 in the placebo group; individuals who received vitamin D presented 2,892 falls versus 769 in the control group. The study concluded that the annual administration of a high dose of vitamin D was associated with a high risk of falls and fractures. Interestingly, in the vitamin $\mathrm{D}$ group there was a $31 \%$ higher incidence of falls in the first 3 months following dosing, and 13\% during the following 9 months [46]. The increase in the risk of falls and fractures with the use of vitamin D megadose has motivated extensive analysis in the literature on the possible mechanisms of action. Dawson-Hughes postulated that the 500000 IU-dose may have triggered a "short-term protective reaction" in which CYP24 was upregulated, and consequently a decreased in blood and tissue levels of $1,25-(\mathrm{OH})_{2}-\mathrm{D}_{3}[47,48]$. Some evidence suggests a $\mathrm{U}$-shaped response to vitamin $\mathrm{D}$ for outcomes including falls and fractures, with lowest risk at moderate levels of serum, and increased risk at low and high vitamin D levels [19] suggesting an increased risk in those with the highest serum 25-OH-D levels [49]. Rossini suggests that a transient increase in bone turnover markers and in bone resorption may explain the negative clinical results obtained in studies using intermittent high dose vitamin $\mathrm{D}$ [50]. These observations raise the question if rapid increases in serum 25-OH-D have adverse musculoskeletal effects, especially in those with normal or close to normal vitamin $\mathrm{D}$ serum values.

The numerous studies conducted with vitamin D supplementation have resulted in contradictory results, making hard to reach a definitive conclusion about the effect of vitamin D on muscle strength as well as the risk of falls and subsequent fractures. In relation to falls, Tang comments that this discrepancy could be attributed to the heterogeneity of the included clinical studies because some have not incorporated all the important parameters in their design to analyze this association, such as the type of population studied (sufficient or deficient vitamin D patients), the form and dose of administration of the supplements and the way to collect information on falls [51].

\section{Dietary requirement of vitamin $D$ and blood levels}

Despite the high prevalence of vitamin D deficiency, there is a debate among different societies regarding the adequate daily intake of vitamin $\mathrm{D}$ as well as the definition of vitamin D deficiency. The Institute of Medicine report recommended that an adequate intake of vitamin D for children under one year of age should be in the range of $400 \mathrm{IU}$ per day, the recommended dietary allowance (RDA) for children $\geq 1$ year and for adults until 70 years old should be in the range of $600 \mathrm{IU}$ per day; whereas for adults over age 70 years should be in the range of 800 IU per day [19]. Some clinical guidelines and other authors recommend considering the RDA values proposed by IOM as the recommended minimum daily intake. It is still not clear whether these values are enough to obtain the extra skeletal benefits of vitamin D [27,52,53] However, these recommendations have been questioned as a daily supplement intake of $600 \mathrm{IU}$ of vitamin $\mathrm{D}$ would not be enough to produce levels of $25-\mathrm{OH}-\mathrm{D} \geq 10 \mathrm{ng} / \mathrm{ml}(25 \mathrm{nmol} / \mathrm{L})$ [53].

The American Association of Clinical Endocrinologists for patients at risk for vitamin D deficiency recommend the intakes of $400 \mathrm{IU}$ per day for children under 1 year of age, and 600 IU for children 1 year and older to maximize bone health, but 1,000 IU per day are needed to raise the blood level of 25-(OH)-D consistently above $30 \mathrm{ng} / \mathrm{ml}$. In adults older than 18 years, 1,500 to $2,000 \mathrm{IU}$ per day are required to achieve this same goal [27]. The recommended dietary allowance 
(RDA) for pregnant and breastfeeding women is $600 \mathrm{IU}$ of vitamin $\mathrm{D}$, but in order to raise the values of $25-(\mathrm{OH})-\mathrm{D}$ over $30 \mathrm{ng} / \mathrm{ml}(75$ $\mathrm{nmol} / \mathrm{L}$ ), it is required 1,500 to $2,000 \mathrm{IU}$ per day at least. Double or triple doses of vitamin D may be needed for obese children and adults at all age and for those receiving corticosteroids, anticonvulsants, antifungal like ketoconazole, and medicine used in HIV treatment [27]. The measurement of 25-(OH)-D in the serum reflects the body reserve of this vitamin, which derives from skin synthesis and vitamin $\mathrm{D}$ intake (diet and supplements). Measurement of this metabolite is an acceptable indicator of its status in the human body and represents the test of choice to identify the sufficiency or deficiency of vitamin D [54].

It is generally considered that $25-(\mathrm{OH})$-D values under $8-10$ $\mathrm{ng} / \mathrm{ml}$ (20-25 $\mathrm{nmol} / \mathrm{L})$ induce osteomalacia; 25-(OH)-D values between $10-16 \mathrm{ng} / \mathrm{ml}(25-40 \mathrm{nmol} / \mathrm{L})$ are associated with secondary hyperparathyroidism and osteoporosis, and levels above $20 \mathrm{ng} / \mathrm{ml}$ were considered normal [55]. However, some investigators report that values of at least $30 \mathrm{ng} / \mathrm{ml}(75 \mathrm{nmol} / \mathrm{L})$ of $25-(\mathrm{OH})-\mathrm{D}$ in serum are required in order to maximize the beneficial effects on health [56]. The maximum reference value of $25-(\mathrm{OH})-\mathrm{D}$ in serum is not clearly defined either, but for some authors the toxicity value begins approximately at $100 \mathrm{ng} /$ $\mathrm{ml}(250 \mathrm{nmol} / \mathrm{L})$ [57]. The IOM report defines vitamin D deficiency when $25-(\mathrm{OH})-\mathrm{D}$ values are below $20 \mathrm{ng} / \mathrm{ml}(50 \mathrm{nmol} / \mathrm{L})$. This report concludes that serum levels of 25-(OH)-D of $16 \mathrm{ng} / \mathrm{ml}(40 \mathrm{nmol} / \mathrm{L})$ meet the requirements of approximately half of the population, levels of $25-(\mathrm{OH})-\mathrm{D}$ of $20 \mathrm{ng} / \mathrm{ml}(50 \mathrm{nmol} / \mathrm{L})$ meet the requirements of more than $97.5 \%$ of the population, and levels of $25-(\mathrm{OH})-\mathrm{D}$ above $50 \mathrm{ng} / \mathrm{ml}(125$ $\mathrm{nmol} / \mathrm{L}$ ) could be associated to adverse events [19]. Recommendations for administration of vitamin D from the UK National Osteoporosis Society (NOS), also define vitamin D deficiency when values are below $12 \mathrm{ng} / \mathrm{ml}(30 \mathrm{nmol} / \mathrm{L})$, levels between 12 and $20 \mathrm{ng} / \mathrm{ml}$ (30 and 50 $\mathrm{nmol} / \mathrm{L}$ ) are inadequate to some people, and levels above $20 \mathrm{ng} / \mathrm{ml}$ (50 $\mathrm{nmol} / \mathrm{L}$ ) define vitamin D sufficiency for most individuals [58].

The consensus of the American Association of Clinical Endocrinologists defines vitamin $\mathrm{D}$ deficiency when the values of 25-(OH)-D are below $20 \mathrm{ng} / \mathrm{ml}(50 \mathrm{nmol} / \mathrm{L})$, insufficiency when they are between $21-29 \mathrm{ng} / \mathrm{ml}(52.5-72.5 \mathrm{nmol} / \mathrm{L})$; and sufficiency when they are $30 \mathrm{ng} / \mathrm{ml}(75 \mathrm{nmol} / \mathrm{L})$; and the safety margin to minimize the risk of hypercalcemia is defined when the value of $25-(\mathrm{OH})-\mathrm{D}$ is $\geq 100 \mathrm{ng} /$ $\mathrm{ml}(250 \mathrm{nmol} / \mathrm{L})$ [27]. However, there is also controversy regarding the definition of vitamin D deficiency; in the recent NOF guidelines for the management of osteoporosis, it is also recommended that optimum value of $25-(\mathrm{OH})-\mathrm{D}$ must be $30 \mathrm{ng} / \mathrm{ml}(75 \mathrm{nmol} / \mathrm{L})$, otherwise it would be classified as vitamin D deficiency [59].

\section{Vitamin D deficiency and its consequences}

In past decades, studies have found $12.5 \%$ to $76 \%$ of osteoporotic postmenopausal women with vitamin D values below $12 \mathrm{ng} / \mathrm{ml}$, with regional and seasonal variations; and this deficiency is accentuated in direct proportion to the age of studied group, influencing negatively to bone metabolism [60]. In states of vitamin D deficiency, decreased calcium absorption in the intestine causes secondary hyperparathyroidism, resulting in bone loss. In addition, loss of renal phosphate alters the calcium-phosphate products causing reduced mineralization of bone matrix, the latter effect can result in rickets in children and osteomalacia in adults. Vitamin D, by increasing calcium absorption, prevents hyperparathyroidism and benefits the development of optimal bone mass and proper bone matrix mineralization. Both factors are responsible for optimizing the mechanical strength of bone $[4,27,52]$. In children, an adequate consumption of vitamin D is related to an increased gain of bone mass in proper conditions of calcium ingestion [61]. This is important because in late adolescence, $25-50 \%$ of the peak bone mass is reached during this period [62] so deficient ingestion of calcium and vitamin $\mathrm{D}$ has deleterious effects on the peak bone mass that will be reached in adulthood. Vitamin D deficiency is related to decreased bone mass in children; and with a high increase in the risk of fractures, particularly at distal radius [63,64].

In pregnant women, vitamin D deficiency is related to an elevated rate of bone turnover, loss of bone mass, osteomalacia, myopathy, and an increased risk of preeclampsia and cesarean section [27,65]. Maternal vitamin D deficiency is correlated with neonatal vitamin $\mathrm{D}$ deficiency and can have a negative effect on fetal skeletal mineralization and development, which can result in congenital rickets, craniotabes, and poor bone mineral content $[65,66]$. Vitamin D deficiency in pregnant women and its implications for the mother and fetus health has led some experts in this area to recommend the screening for hypovitaminosis D in all patients in early pregnancy [65]. In the elderly, low vitamin D levels along with other factors, represent the first step towards secondary hyperparathyroidism, which leads silently to bone loss, especially at the cortical regions. This step may be reversed by the administration of vitamin D [67]. In this age group, in addition to the deleterious effects on bone, consequences of vitamin $\mathrm{D}$ deficiency on muscle are well known, causing muscle strength and function decrease, which results in muscle weakness and poor motor coordination, which can result in falls and increased risk of fractures [68]. In the elderly, vitamin $\mathrm{D}$ deficiency is considered a risk factor for falls and fractures. The effects of vitamin D deficiency on muscle may occur even before bone changes are developed [69]. An important aspect that we should consider as clinicians is that osteomalacia occurs if hypovitaminosis $\mathrm{D}$ is severe and long standing. Mild or moderate hypovitaminosis D cannot produce osteomalacia, but it can contribute to the development of osteoporosis and the alteration of muscular function, so most of the consensus emphasizes the importance of early correction of the vitamin $\mathrm{D}$ deficiency as part of the comprehensive management of osteoporosis [70-72].

Finally, the efficacy of medications for osteoporosis has been demonstrated in a number of clinical studies related to calcium and vitamin $\mathrm{D}$; and it is considered that this vitamin maximizes the effectiveness of the drug prescribed for prevention of fractures with a good safety profile $[73,74]$. Carmel et al reported that patients with a mean $25-(\mathrm{OH})-\mathrm{D} \geq 33 \mathrm{ng} / \mathrm{ml}(82.3 \mathrm{nmol} / \mathrm{L})$ had a greater probability of maintaining the bisphosphonate response [75]. For these reasons, it is advisable to correct the deficiency of vitamin $\mathrm{D}$ and to maintain optimum levels before starting the treatment for osteoporosis.

\section{What form of Vitamin D should we recommend, and which route?}

The cholecalciferol and ergosterol metabolic pathways are similar, when either form of vitamin $\mathrm{D}$ is administered, they transform initially in $25-(\mathrm{OH})-\mathrm{D}$, and then in $1,25-(\mathrm{OH})_{2}-\mathrm{D}$. 1,25- $(\mathrm{OH})_{2}-\mathrm{D}_{3}$ controls its own synthesis due to feedback regulation mechanisms $[4,76]$ so, when cholecalciferol or ergocalciferol is administered, even in supraphysiological doses, there is a minimum risk for adverse events. The excess of vitamin $\mathrm{D}$ is stored in body fat and transforms itself according to the daily physiological requirements [13]. When $1,25-(\mathrm{OH})_{2}-\mathrm{D}_{3}$ (calcitriol) is administered, a direct pharmacological effect is observed and may cause hypercalcemia, with a subsequent risk of hypercalciuria and renal lithiasis $[68,77,78]$. Alfacalcidiol $\left(1-\alpha-(\mathrm{OH})-\mathrm{D}_{3}\right)$ is a synthetic inactive pro-hormone that must be hydroxylated in the liver to 
transform into 1,25- $(\mathrm{OH})_{2}-\mathrm{D}_{3}$. Just as calcitriol, this form surpasses the vitamin $\mathrm{D}$ synthesis main control mechanism, which is hydroxylation in position 1 in the kidney, thus its administration must be considered a pharmacological treatment. However, when calcitriol or alfacalcidiol are used, the problem of filling body deposits with vitamin $\mathrm{D}$ is not solved [79-81].

Calcitriol, alfacalcidiol and other analogs are used in the management of patients with chronic kidney diseases, whose kidney hydroxylation is diminished; and also have shown to be useful when surpassing the regulatory mechanism is needed, like with vitamin D resistant rickets [81-83]. However, it is not advisable to use calcitriol or alfacalcidiol to correct a vitamin D deficiency in all patients, since a direct pharmacological effect would be applied, which is beyond the control of the regulatory mechanisms $[79,82]$. Both vitamin D3 (cholecalciferol) and vitamin D2 (ergocalciferol) are effective in correcting and keeping serum levels of 25-(OH)-D [27], but they are not bioequivalents [84]. Since 1930, Hess suggested that the activity of cod liver oil, which contains vitamin $\mathrm{D} 3$, was different from the biological value of vitamin D2, which was obtained from UV irradiation of ergot of rye or from lipid yeast extract, called "viosterol". This was then the patented and licensed form of synthesis of vitamin D2 by pharmaceutical companies at that time [85]. When the efficacy of cholecalciferol and ergocalciferol is compared in elevating the serum levels of $25-(\mathrm{OH})-\mathrm{D}$, the increase is $70 \%$ greater with cholecalciferol in relation to ergosterol [86], and a 2.5fold higher dose of ergocalciferol is needed to obtain a similar plasma concentration of $25-(\mathrm{OH})-\mathrm{D}$ than that observed with cholecalciferol [87]. Additionally, ergocalciferol is less stable than cholecalciferol [88].

Armas evaluated the efficacy in elevating the concentrations of 25- $(\mathrm{OH})$-D with single doses of cholecalciferol or ergocalciferol orally, for 28 days. Both forms of vitamin $\mathrm{D}$ were associated with a rapid elevation of 25-(OH)-D in the plasma during the first 3 days; however, with ergocalciferol, the maximum plasma concentration is reached on the 14th day of administration and, subsequently, on the 28th day, it falls below the baseline value. With cholecalciferol the values of 25-(OH)-D in the plasma also reach their maximum concentration on the 14th day after its administration, however, they remained elevated above the baseline value at $28^{\circ}$ day. The area under the curve of both forms of vitamin $\mathrm{D}$, showed that cholecalciferol is three times more potent than ergocalciferol [84].

A meta-analysis that compares the efficacy of vitamin D2 and vitamin D3 in raising serum 25-OH-D levels concludes that vitamin D3 is more efficacious at raising serum $25-(\mathrm{OH})-\mathrm{D}$ concentrations than vitamin $\mathrm{D} 2(\mathrm{P}=0.001)$, and favor the supplement with cholecalciferol over ergocalciferol [76]. Finally, there are published recommendations for supplementation of vitamin D. A recent study analyzes the efficiency of a single mega dose of 300,000 IU of cholecalciferol or ergocalciferol, administered orally and intramuscular, monitoring for 60 days in women who lived in nursing homes. The authors found a significant rise of 25-(OH)-D over baseline only when cholecalciferol or ergocalciferol were administrated orally; reaching the desired or ideal value of $32 \mathrm{ng} /$ $\mathrm{ml}(80 \mathrm{nmol} / \mathrm{L})$ of $25-(\mathrm{OH})-\mathrm{D}$ in a rapid and consistent manner [89]. With the intramuscular application of both forms of vitamin $\mathrm{D}$, there was a slow, continuous and progressive rise of 25-(OH)-D levels during the period of observation of the study, and a level $32 \mathrm{ng} / \mathrm{ml}(80 \mathrm{nmol} / \mathrm{L})$ of $25-(\mathrm{OH})-\mathrm{D}$ in the serum was reached within just 60 days of the study. Differences in the serum concentration of 25- $(\mathrm{OH})$-D over the baseline were significantly better with cholecalciferol administered orally within 30 days in regard with the other forms of administration. Authors conclude that cholecalciferol was at least two times more efficient than ergocalciferol to increase serum concentrations of 25-(OH)-D; but also, the best route of administration of this vitamin is oral [89].

\section{What level of 25-OH-D should we reach?}

The purpose of vitamin D supplementation is to maximize calcium absorption and to reduce deleterious effects of a PTH rise on the bone. Supplementation with vitamin D may also reduce the risk of fractures, improve bone mass and optimize the response to antiresorptive or anabolic agents $[4,74,75,90]$. However, what is the optimal level of $25-(\mathrm{OH})-\mathrm{D}$ to be reached in the serum and with which of these objectives can be achieved? From a biochemical point of view, the maximal suppression of the circulating PTH concentrations, and maximization of calcium absorption are considered the most important endpoints $[91,92]$. Some studies suggest that in subjects with a serum concentration of $25-(\mathrm{OH})-\mathrm{D}$ between $30-40 \mathrm{ng} / \mathrm{ml}$, the connection between $25-(\mathrm{OH})-\mathrm{D}$ and serum $\mathrm{PTH}$, becomes inversely proportional significantly; in a way that with serum values of $25-(\mathrm{OH})-\mathrm{D}$ above this level, concentration PTH is minimized [92-95]. Studies have determined that with levels of $25-(\mathrm{OH})-\mathrm{D}$ above $34.6 \mathrm{ng} / \mathrm{ml}(86.4 \mathrm{nmol} / \mathrm{L})$, calcium absorption is increased by $45 \%-65 \%$ compared to levels of $20 \mathrm{ng} / \mathrm{ml}$ ( 50 $\mathrm{nmol} / \mathrm{L})[94,96]$.

Using the value of at least $30 \mathrm{ng} / \mathrm{ml}(75 \mathrm{nmol} / \mathrm{L})$ as cut-off point and comparing it with the most important clinical objective, incident fractures, in studies with vitamin D supplement increased the serum concentrations of 25-(OH)-D to values between 28.4 to $39.6 \mathrm{ng} / \mathrm{ml}$ (71 to $99 \mathrm{nmol} / \mathrm{L})$, there was a significant reduction in fracture rate; while studies with the serum concentrations of $25-(\mathrm{OH})$-D were increased to values between 21.6 to $24.8 \mathrm{ng} / \mathrm{ml}(54-62 \mathrm{nmol} / \mathrm{L})$, there was no evidence of reduction in fracture risk [96]. The IOF position statement on vitamin $\mathrm{D}$ for older adults recommends that the estimated average vitamin D requirement to reach a serum 25-OH-D level of $30 \mathrm{ng} / \mathrm{ml}$ $(75 \mathrm{nmol} / \mathrm{L})$ is 800 to $1,000 \mathrm{IU} /$ day, but considerably higher doses or a repletion dose would be needed to reach this level in almost all older adults [47]. The next question often asked is for how long is it required to supplement the recommended daily dose of vitamin D (at least 800 IU daily) to reach this value? A recent study evaluated the effects of a daily dose of $800 \mathrm{IU}$ in a group of African American women, this study had a $25-(\mathrm{OH})-\mathrm{D}$ baseline value of $18.8 \mathrm{ng} / \mathrm{ml}(46.9 \mathrm{nmol} / \mathrm{L})$, after treatment this value increased significantly by the third month to $28.6 \mathrm{ng} / \mathrm{ml}(71.4 \mathrm{nmol} / \mathrm{L})$, and by the 24 th month, the value was of $26.4 \mathrm{ng} / \mathrm{ml}(65.9 \mathrm{nmol} / \mathrm{L})$. At 24 th month of the study, the vitamin $\mathrm{D}$ dose was increased to 2,000 IU daily; and the levels that were at 26.4 $\mathrm{ng} / \mathrm{ml}(65.9 \mathrm{nmol} / \mathrm{L})$, increased to $34.9 \mathrm{ng} / \mathrm{ml}(87.2 \mathrm{nmol} / \mathrm{L})$ [97]. This work had several implications. In this group of patients with vitamin $\mathrm{D}$ deficiency, the administration of the recommended daily dose (800 IU daily) and maintained at the same dose for two years did not significantly increased the $25-(\mathrm{OH})-\mathrm{D}$ values to a level considered as adequate. Therefore, administration of the dose equivalent to the daily requirement $(800 \mathrm{IU})$ to patients with a vitamin $\mathrm{D}$ deficiency does not permit them to achieve the desired serum levels, nor correct the deficiency [97].

In another study composed mostly of Caucasian women, $40 \%$ of subjects had serum 25-(OH)-D levels $<30 \mathrm{ng} / \mathrm{ml}$ and after 12 months of oral vitamin $\mathrm{D}$ supplementation at doses of 1,600 IU/ daily or 50,000 IU once per month, $19 \%$ of subjects remained with low $25-(\mathrm{OH})-\mathrm{D}$ levels. The authors concluded that vitamin $\mathrm{D}$ doses greater than 1,600 IU daily are required to ensure adequacy in all individuals [98]. A recent study, designed to evaluate the prevalence of vitamin $\mathrm{D}$ deficiency in postmenopausal women receiving treatment 
for osteoporosis, included a population of 1,536 postmenopausal women, who received alendronate, calcitonin, etidronate, raloxifene, risedronate, or teriparatide, for a minimum of three months, to prevent or to treat osteoporosis, in addition to calcium and vitamin D. The investigators reported an average serum concentration of $25-(\mathrm{OH})-\mathrm{D}$ of $30.4 \pm 13.2 \mathrm{ng} / \mathrm{ml}(75.8 \pm 32.9 \mathrm{nmol} / \mathrm{L})$; but $52 \%$ of the patients had suboptimal levels of $25-(\mathrm{OH})-\mathrm{D}$ (defined as $<30 \mathrm{ng} / \mathrm{ml}$ or $75 \mathrm{nmol} / \mathrm{L}$ ), and in $18 \%$, below $20 \mathrm{ng} / \mathrm{ml}(50 \mathrm{nmol} / \mathrm{L})$. The prevalence of suboptimal levels of 25-hidroxyvitamin D was even higher in those who received supplements of vitamin D under 400 IU daily, in comparison to those who received daily higher supplements [95]. The authors concluded that there was an unacceptable high prevalence of vitamin D deficiency in postmenopausal women, despite being treated for osteoporosis; and that patients as well as physicians must be educated about the importance of optimize the status of vitamin $\mathrm{D}$ to improve the therapeutic response of patients with osteoporosis [95].

Adami evaluated 1,515 postmenopausal women with osteoporosis in treatment with alendronate, risedronate or raloxifene during an average of 13.1 months, and a treatment adherence (> 75\%). Patients were classified in two groups that included vitamin $\mathrm{D}$ deficiency $(\mathrm{n}=514)$ or vitamin D sufficiency $(\mathrm{n}=1,001)$. The investigators found a significantly greater increase in bone mineral density in the lumbar spine, femoral neck, and total hip in women with sufficient levels of vitamin $\mathrm{D}$. The adjusted incidence of clinical fractures was $77 \%$ higher in women with a deficiency of vitamin $\mathrm{D}(25-(\mathrm{OH})-\mathrm{D}<20 \mathrm{ng} / \mathrm{ml}(50$ $\mathrm{nmol} / \mathrm{L}$ ) (RO 1,77; IC 95\%: 1,20-2,59 p=0,004) [73]. These studies emphasize the importance of correcting vitamin $\mathrm{D}$ deficiency in patients with osteoporosis to obtain an adequate response to treatment. However, administering the dose equivalent to the daily requirement, for a person with insufficiency or deficiency of this vitamin, does not always correct the deficiency and does not improve vitamin D reserves.

\section{Treatment of vitamin $\mathrm{D}$ deficiency}

To correct vitamin $\mathrm{D}$ deficiency, doses higher than the daily requirement are needed and treatment should be aimed at normalizing serum 25-(OH)-D values and replenishing vitamin D stores. After correcting the deficiency, the daily requirement must be continued. The form of vitamin $\mathrm{D}$ to be chosen, the dose and the treatment schedule may vary according to the severity of the deficiency, age, and body weight [99]. It should also be taken into account that levels of 25-(OH)-D in response to vitamin $\mathrm{D}$ intake appear to be quite variable; some people remain deficient, while others respond with high and undesirable levels of 25-(OH)-D following the same recommendations [100].

Vitamin D has a long half-life and supplements can be prescribed for longer intervals than daily administration. Adherence to treatment is important; and since different daily, weekly or monthly schedules have shown efficacy in correcting vitamin D deficiency this aspect should be considered to improve adherence [101]. Supplementation with vitamin $\mathrm{D}$ increases serum 25-OH-D levels, but some special situations require higher doses of vitamin $\mathrm{D}$ as in obese patients or in those subjects who concomitantly receive medications that interact with the metabolism of vitamin D (E.g. Anticonvulsive medications, glucocorticoids, cholestyramine, ketoconazole), a 2 to 3 times higher doses are often required to treat and prevent vitamin $\mathrm{D}$ deficiency in these cases [27]. For the reasons reviewed previously, cholecalciferol is considered the vitamin $\mathrm{D}$ form of choice for the treatment, and oral administration is preferred to intramuscular [58,102]. It is estimated that in healthy adults, ingestion of $100 \mathrm{IU}$ of vitamin D increases $25-(\mathrm{OH})-\mathrm{D}$ levels by approximately 0.7 to $1 \mathrm{ng} / \mathrm{ml}$ [99], but in some situations, such as in those subjects who are going to start treatment with antiresorptive medications or with severe and symptomatic deficiency, a rapid correction can be achieved with higher doses of vitamin D [58]. Loading doses of 300,000 IU and even $\geq 100,000$ for some guidelines are not recommended, because high intermittent loading doses have shown a paradoxical increased in falls and fractures [46]. Indeed, a number of studies using bolus dosing of 300,000-600,000 IU of vitamin D2 or vitamin D3 have shown a paradoxical increased rate of adverse events, including falls and fractures $[46,58,103]$.

Different dose schemes have been proposed to correct vitamin D deficiency. Some propose a fixed dose, while others stratify the dose according to the values of 25-(OH)-D in the serum (Table 2). One of the recommended alternatives is to administer 50,000 IU of vitamin D once a week for 8 weeks or 5000 to $6000 \mathrm{IU} / \mathrm{d}$ of vitamin D for 8 weeks $[27,99]$. The latest French Osteoporosis Research and Information Group (GRIO) guidelines for patients with or at risk for osteoporosis recommend stratifying the number of loading doses according to the value of 25-(OH)-D [104]. If the values are below $20 \mathrm{ng} / \mathrm{ml}, 50,000 \mathrm{IU}$ of vitamin D3 should be administered weekly for 8 weeks, but if the values are between 20 and $30 \mathrm{ng} / \mathrm{ml}$ they recommend administering the loading dose of 50,000 only for 4 weeks [105-107]. Another proposed alternative is to administer a total dose of approximately 300,000 IU during 6-10 weeks, daily or weekly [58]. Finally, it is up to the clinician to choose the dosing regimen that is convenient for correcting vitamin $\mathrm{D}$ deficiency in any particular patient and consider that the maintenance dose should be continued indefinitely.

For cut-off points to determine the status of vitamin D and the population group to which these guidelines are directed (eg adults, postmenopausal women) please review the specific references

US ES (US Endocrine Society): Vitamin D deficiency is defined as a $25-(\mathrm{OH})-\mathrm{D}$ below $20 \mathrm{ng} / \mathrm{ml}(50 \mathrm{nmol} / \mathrm{L})$, and vitamin $\mathrm{D}$ insufficiency as a $25-(\mathrm{OH})-\mathrm{D}$ of $21-29 \mathrm{ng} / \mathrm{ml}(525-725 \mathrm{nmol} / \mathrm{L})$.

Table 2. Treatment for vitamin D deficiency in adults. For cut-off points to determine the status of vitamin D and the population group to which these guidelines are directed (eg adults, postmenopausal women) please review the specific references.

\begin{tabular}{|c|c|}
\hline Institution & Recommendation \\
\hline US ES [27] & $\begin{array}{l}50,000 \mathrm{IU} \text { of vitamin D once a week for } 8 \text { weeks or } 6000 \mathrm{IU} / \text { day } \\
\text { of vitamin D } \\
\text { Maintenance doses: } 1,500-2,000 \mathrm{UI} / \mathrm{d}\end{array}$ \\
\hline NOS [58] & $\begin{array}{l}\text { For rapid correction: A fixed loading regimen to provide a total } \\
\text { of } \approx 300000 \mathrm{IU} \text { of vitamin } \mathrm{D} \text {, given either as separate weekly or } \\
\text { daily doses over } 6-10 \text { weeks }^{2} \\
\text { Maintenance doses: } 800-2,000 \mathrm{IU} / \mathrm{d} \text { (occasionally up to } 4,000 \mathrm{IU} \\
\text { daily), given either daily or intermittently at higher doses }\end{array}$ \\
\hline $\begin{array}{l}\text { EMA } \\
\text { State }\end{array}$ & $\begin{array}{l}\text { Women with serum } 25-(\mathrm{OH})-\mathrm{D} \text { levels }<20 \mathrm{ng} / \mathrm{ml}: 4000-10,000 \\
\mathrm{IU} / \text { day to achieve adequate levels }(>30 \mathrm{ng} / \mathrm{ml})\end{array}$ \\
\hline Italian AME [99] & $\begin{array}{l}50,000 \mathrm{IU} \text { of vitamin D once a week for } 8 \text { weeks or daily dose of } \\
5000 \mathrm{IU} \text { of vitamin D for } 8 \text { weeks } \\
\text { Maintenance doses: } 50,000 \mathrm{IU} \text { twice a month; or a daily dose of } \\
2000 \mathrm{IU}\end{array}$ \\
\hline $\begin{array}{l}\text { Central Europe } \\
\text { Practical guidelines } \\
{[103]}\end{array}$ & $\begin{array}{l}1,000-10,000 \mathrm{IU} / \text { day }(\approx 50,000 \mathrm{IU} / \text { week }) \text {, depending on the } \\
\text { patient's age and body weight from } 1-3 \text { months }\end{array}$ \\
\hline $\begin{array}{l}\text { Saudi Arabia expert } \\
\text { consensus [107] }\end{array}$ & $\begin{array}{l}50,000 \mathrm{IU} \text { once weekly for } 8 \text { weeks or } 6000 \mathrm{IU} / \mathrm{day}^{3} \\
\text { Maintenance doses: } 1000-2000 \mathrm{IU} / \text { day once serum } 25-(\mathrm{OH})-\mathrm{D} \\
\text { level is above } 30 \mathrm{ng} / \mathrm{ml}\end{array}$ \\
\hline $\begin{array}{l}\text { Groupe de recherche } \\
\text { et d'information } \\
\text { surles ostéoporoses, } \\
\text { (GRIO) [105] }\end{array}$ & $\begin{array}{l}25-(\mathrm{OH})-\mathrm{D}<20 \mathrm{ng} / \mathrm{ml}: 50,000 \mathrm{IU} \text { of vitamin } \mathrm{D} 3 \text { per week for } 8 \\
\text { weeks } \\
25-(\mathrm{OH})-\mathrm{D} 20-30 \mathrm{ng} / \mathrm{ml}: 50,000 \mathrm{IU} \text { of vitamin D3 per week for } \\
4 \text { weeks } \\
\text { After loading phase, long term supplementation with } 50,000 \mathrm{IU} \\
\text { of vitamin D3 per month. If } 25-(\mathrm{OH})-\mathrm{D} \text { is still }<30 \mathrm{ng} / \mathrm{mL} \text { after } \\
3-6 \text { months, shorten the dose interval (e.g., } 50,000 \mathrm{IU} \text { every two } \\
\text { weeks) or increase dosage (e.g., to } 80,000 \text { or } 100,000 \text { each month }\end{array}$ \\
\hline
\end{tabular}


NOS (UK National Osteoporosis Society): Less than $30 \mathrm{nmol} / \mathrm{L}$ is deficient; $30-50 \mathrm{nmol} / \mathrm{L}$ may be inadequate in some people and greater than $50 \mathrm{nmol} / \mathrm{L}$ is sufficient.

EMAS (European Menopause and Andropause Society): Insufficiency if serum 25-(OH)-D levels are between 20 and $29.99 \mathrm{ng} /$ $\mathrm{ml}$, deficiency below $20 \mathrm{ng} / \mathrm{ml}$, and severe deficiency below $10 \mathrm{ng} / \mathrm{ml}$.

AME (Italian Association of Clinical Endocrinologists and Italian Chapter of the American Association of Clinical Endocrinologists)

1. Vitamin D3 of choice. For adults who are vitamin D deficient to achieve a blood level of 25-(OH)-D above $30 \mathrm{ng} / \mathrm{ml}$.

2. For rapid correction only for symptomatic disease or for patients at an increased risk of hypocalcemia, about to receive potent antiresorptive medication.

3. For postmenopausal women with severe vitamin D deficiency $(<10$ $\mathrm{ng} / \mathrm{ml}$ ) and elderly at risk for fall and osteoporotic fractures

Central Europe Practical Guidelines: concentrations below 20 ng/ $\mathrm{ml}(50 \mathrm{nmol} / \mathrm{L})$ indicate Vitamin D deficiency, which should be treated medically; concentrations of $20 \mathrm{ng} / \mathrm{ml}(50 \mathrm{nmol} / \mathrm{L})$ up to $30 \mathrm{ng} / \mathrm{ml}(75$ $\mathrm{nmol} / \mathrm{L}$ ) reflect a suboptimal Vitamin D status that calls for a moderate increase of Vitamin D daily dose; concentrations higher than $30 \mathrm{ng} / \mathrm{ml}$ $(75 \mathrm{nmol} / \mathrm{L})$ up to $50 \mathrm{ng} / \mathrm{ml}(125 \mathrm{nmol} / \mathrm{L})$ reflect adequate Vitamin $\mathrm{D}$ status.

\section{References}

1. Norman AW (2008) From vitamin D to hormone D: fundamentals of the vitamin D endocrine system essential for good health. Am J Clin Nutr 88: 491S-499S. [Crossref]

2. Prietl B, Treiber G, Pieber TR, Amrein K (2013) Vitamin D and immune function. Nutrients 5: 2502-2521. [Crossref]

3. Bouillon R, Bikle D2 (2019) Vitamin D Metabolism Revised: Fall of Dogmas. J Bone Miner Res 34: 1985-1992. [Crossref]

4. Bikle DD (2014) Vitamin D metabolism, mechanism of action, and clinical applications. Chem Biol 21: 319-329. [Crossref]

5. Nesterova G, Malicdan MC, Yasuda K, Sakaki T, Vilboux T, et al. (2013) 1,25-(OH)2D-24 Hydroxylase (CYP24A1) Deficiency as a Cause of Nephrolithiasis. Clin J Am Soc Nephrol 8: 649-657. [Crossref]

6. Jones G, Prosser DE, Kaufmann M (2014) Cytochrome P450-mediated metabolism of vitamin D. J Lipid Res 55: 13-31. [Crossref]

7. Holick MF (2002) Vitamin D: the underappreciated D-lightful hormone that is important for skeletal and cellular health. Curr Opin Endocrinol Diabetes 9: 87-98.

8. Clemens TL, Adams JS, Henderson SL, Holick MF (1982) Increased skin pigment reduces the capacity of skin to synthesise vitamin D3. Lancet 1: 74-76. [Crossref]

9. Matsuoka LY, Ide L, Wortsman J, MacLaughlin J, Holick MF (1987) Sunscreens suppress cutaneous vitamin D3 synthesis. J Clin Endocrinol Metab 64: 1165-1168. [Crossref]

10. Jones G, Prosser DE, Kaufmann M (2018) The activating enzymes of vitamin D metabolism (25-and $1 \alpha$-hydroxylases). In Vitamin D 23-42.

11. Barchetta I, Carotti S, Labbadia G, Gentilucci UV, Muda AO, et al. (2012) Liver vitamin D receptor, CYP2R1, and CYP27A1 expression: relationship with liver histology and vitamin D3 levels in patients with nonalcoholic steatohepatitis or hepatitis $\mathrm{C}$ virus. Hepatology 56: 2180-2187. [Crossref]

12. Anderson PH, May BK, Morris HA (2003) Vitamin D metabolism: new concepts and clinical implications. Clin Biochem Rev 24: 13-26. [Crossref]

13. Holick MF (2004) Sunlight and vitamin D for bone health and prevention of autoimmune diseases, cancers, and cardiovascular disease. Am J Clin Nutr 80: 1678S-1688S [Crossref]

14. Barger-Lux MJ, Heaney RP, Dowell S, Chen TC, Holick MF (1998) Vitamin D and its major metabolites: serum levels after graded oral dosing in healthy men. Osteoporos Int 8: 222-230 [Crossref]
15. Dusso AS (2011) Kidney disease and vitamin D levels: 25-hydroxyvitamin D, 1,25-dihydroxyvitamin D, and VDR activation. Kidney Int Suppl (2011) 1: 136-141. [Crossref]

16. Holick MF (2006) Vitamin D deficiency in obesity and health consequences. Curr Opin Endocrinol Diabetes 13: 412-418.

17. Savastano S, Barrea L, Savanelli MC, Nappi F, Di Somma C, et al. (2017) Low vitamin D status and obesity: Role of nutritionist. Rev Endocr Metab Disord 18: 215-225. [Crossref]

18. Kennel KA, Drake MT, Hurley DL (2010) Vitamin D deficiency in adults: when to test and how to treat. Mayo Clin Proc 85: 752-757. [Crossref]

19. Ross AC, Taylor CL, Yaktine AL (2011) Institute of Medicine (US) Committee to Review Dietary Reference Intakes for Vitamin D and Calcium. Dietary Reference Intakes for Calcium and Vitamin D. Washington (DC): National Academies Press USA.

20. Goltzman D, Mannstadt M, Marcocci C (2018) Physiology of the Calcium-Parathyroid Hormone-Vitamin D Axis. Front Horm Res 50: 1-13. [Crossref]

21. Nishimura A, Shinki T, Jin CH, Ohyama Y, Noshiro M, et al. (1994) Regulation of messenger ribonucleic acid expression of 1 alpha,2 5-dihydroxyvitamin D3-24hydroxylase in rat osteoblasts. Endocrinology 134: 1794-1799.

22. Bergwitz C, Jüppner H (2010) Regulation of phosphate homeostasis by PTH, vitamin D, and FGF23. Annu Rev Med 61: 91-104. [Crossref]

23. Bischoff-Ferrari HA (2005) Extra-skeletal effects of vitamin D. Curr Opin Endocrinol Diabetes Obes 12: 464-470.

24. Bikle DD (2007) Vitamin D insufficiency/deficiency in gastrointestinal disorders. $J$ Bone Miner Res 22: 50-54. [Crossref]

25. Reboul E (2015) Intestinal absorption of vitamin D: from the meal to the enterocyte Food Funct 6: 356-362. [Crossref]

26. Hollander D, Rosenstreich SJ, Volwiler W (1971) Role of the duodenum in vitamin D3 absorption in man. Am J Dig Dis 16: 145-149. [Crossref]

27. Holick MF, Binkley NC, Bischoff-Ferrari HA, Gordon CM, Hanley DA, et al (2011) Evaluation, treatment, and prevention of vitamin D deficiency: an Endocrine Society clinical practice guideline. J Clin Endocrinol Metab 96: 1911-1930 [Crossref]

28. Gross C, Stamey T, Hancock S, Feldman D (1998) Treatment of early recurrent prostate cancer with 1, 25-dihydroxyvitamin D3 (calcitriol). J Urol 159: 2035-2040. [Crossref]

29. Gil Á, Plaza-Diaz J (2018) Vitamin D: Classic and Novel Actions. Ann Nutr Metab 72: 87-95. [Crossref]

30. Takahashi N, Udagawa N, Suda T (2014) Vitamin D endocrine system and osteoclasts. BoneKey Rep 5: 495. [Crossref]

31. Chen X, Wang Z, Duan N, Zhu G, Schwarz EM, et al. (2018) Osteoblast-osteoclast interactions. Connect Tissue Res 59: 99-107. [Crossref]

32. Holick MF (2007) Vitamin D deficiency. N Engl J Med 357: 266-281. [Crossref]

33. Conigrave AD (2016) The Calcium-Sensing Receptor and the Parathyroid: Past Present, Future. Front Physiol 7: 563. [Crossref]

34. Baron R, Hesse E (2012) Update on bone anabolics in osteoporosis treatment: rationale, current status, and perspectives. J Clin Endocrinol Metab 97: 311-325. [Crossref]

35. van Driel M, van Leeuwen JPTM2 (2017) Vitamin D endocrinology of bone mineralization. Mol Cell Endocrinol 453: 46-51. [Crossref]

36. Nakamichi Y, Udagawa N2, Suda T3, Takahashi N4 (2018) Mechanisms involved in bone resorption regulated by vitamin D. J Steroid Biochem Mol Biol 177: 70-76. [Crossref]

37. Sapir-Koren R, Livshits G (2011) Bone mineralization and regulation of phosphate homeostasis. IBMS BoneKey 8: 286-300.

38. Bala Y, Seeman E (2015) Bone's material constituents and their contribution to bone strength in health, disease, and treatment. Calc Tissue Int 97: 308-326. [Crossref]

39. Di Gregorio S, Del Rio L, Rodriguez-Tolra J, Bonel E, García M, et al. (2015) Comparison between different bone treatments on areal bone mineral 3 density (aBMD) and bone microarchitectural texture as assessed by the 4 trabecular bone score (TBS). Bone 75: 138-143. [Crossref]

40. Bislev LS, RÃ,dbro LL, Rolighed L, Sikjaer T, Rejnmark L (2019) Bone Microstructure in Response to Vitamin D3 Supplementation: A Randomized Placebo-Controlled Trial. Calcif Tissue Int 104: 160-170. [Crossref] 
41. Bischoff-Ferrari HA, Stahelin HB, Dick W, Akos R, Knecht M, et al. (2003) Effects of vitamin D and calcium supplementation on falls: A randomized controlled trial. J Bone Miner Res 18: 343-351. [Crossref]

42. Geusens P, Vandevyver C, Vanhoof J, Cassiman JJ, Boonen S, et al. (1997) Quadriceps and grip strength are related to vitamin D receptor genotype in elderly nonobese women. J Bone Miner Res 12: 2082-2088 [Crossref]

43. Ceglia L (2008) Vitamin D and skeletal muscle tissue and function. Mol Aspects Med 29: 407-414. [Crossref]

44. Bischoff-Ferrari HA, Dawson-Hughes B, Willett WC, Staehelin HB, Bazemore MG, et al. (2004) Effect of Vitamin D on falls: a meta-analysis. JAMA 291: 1999-2006. [Crossref]

45. Murad MH, Elamin KB, Abu Elnour NO, Elamin MB, Alkatib AA, et al. (2011) Clinical review: The effect of vitamin D on falls: a systematic review and meta-analysis. J Clin Endocrinol Metab 96: 2997-3006. [Crossref]

46. Sanders KM, Stuart AL, Williamson EJ, Simpson JA, Kotowicz MA, et al. (2010) Annual high-dose oral vitamin $\mathrm{D}$ and falls and fractures in older women: a randomized controlled trial. JAMA 303: 1815-1822 [Crossref]

47. Dawson-Hughes B, Harris SS (2010) High-dose vitamin D supplementation: too much of a good thing? JAMA 303: 1861-1862. [Crossref]

48. Ross AC, Manson JE, Abrams SA, Aloia JF, Brannon PM, et al. (2011) The 2011 Dietary Reference Intakes for Calcium and Vitamin D: what dietetics practitioners need to know. J Am Diet Assoc 111: 524-527. [Crossref]

49. Sanders KM, Nicholson GC, Ebeling PR (2013) Is High Dose Vitamin D Harmful? Calcif Tissue Int 92: 191-206. [Crossref]

50. Rossini M, Adami S, Viapiana O, Fracassi E, Idolazzi L, et al. (2012) Dose-Dependent Short-Term Effects of Single High Doses of Oral Vitamin D3 on Bone Turnover Markers. Calcif Tissue Int 91: 365-369. [Crossref]

51. Tang O, Juraschek S, Appel L (2018) Design features of randomized clinical trials of vitamin D and falls: A systematic review. Nutrients 10: 964. [Crossref]

52. Pramyothin P, Holick MF (2012) Vitamin D supplementation: guidelines and evidence for subclinical deficiency. Curr Opin Gastroenterol 28: 139-150. [Crossref]

53. Heaney RP, Holick MF (2011) Why the IOM recommendations for vitamin D are deficient. J Bone Miner Res 26: 455-457. [Crossref]

54. Lips P (2007) Relative value of 25(OH)D and 1,25(OH)2D measurements. $J$ Bone Miner Res 22: 1668-1671. [Crossref]

55. Vieth R (1999) Vitamin D supplementation, 25-hydroxyvitamin D concentrations, and safety. Am J Clin Nutr 69: 842-856. [Crossref]

56. Holick MF (2003) Vitamin D: A millenium perspective. J Cell Biochem 88: 296-307. [Crossref]

57. Hollis BW (2005) Circulating 25-hydroxyvitamin D levels indicative of vitamin D sufficiency: implications for establishing a new effective dietary intake recommendation for vitamin D. J Nutr 135: 317-322. [Crossref]

58. Aspray TJ, Bowring C, Fraser W, Gittoes N, Javaid MK, et al. (2014) National osteoporosis society vitamin D guideline summary. Age Ageing 43: 592-595. [Crossref]

59. Cosman F, de Beur SJ, LeBoff MS, Lewiecki EM, Tanner B, et al. (2014) Clinician's guide to prevention and treatment of osteoporosis. Osteoporos Int 25: 2359-2381. [Crossref]

60. Gaugris S, Heaney RP, Boonen S, Kurth H, Bentkover JD, et al. (2005) Vitamin D inadequacy among post-menopausal women: a systematic review. QJM 98: 667-676. [Crossref]

61. Viljakainen HT, Natri AM, Kärkkäinen M, Huttunen MM, Palssa A, et al. (2006) A positive dose-response effect of vitamin d supplementation on site-specific bone mineral augmentation in adolescent girls: A double-blinded randomized placebocontrolled 1-year intervention. J Bone Miner Res 21: 836-844. [Crossref]

62. Weaver CM (2006) Prepuberty and adolescence. In: Weaver CM, Heaney RP (eds) Calcium in human Health. Totowa, New Jersey: Humana Press. pp: 281-296.

63. Ryan LM, Teach SJ, Singer SA, Wood R, Freishtat R, et al. (2012) Bone mineral density and vitamin $\mathrm{D}$ status among African American children with forearm fractures. Paediatrics 130: e553-e560. [Crossref]

64. Saggese G, Vierucci F, Boot AM, Czech-Kowalska J, Weber G, et al. (2015) Vitamin $\mathrm{D}$ in childhood and adolescence: an expert position statement. Eur J Pediatr 174: 565576. [Crossref]
65. van der Meer IM, Karamali NS, Boeke AJ, Lips P, Middelkoop BJ, et al. (2006) High prevalence of vitamin D deficiency in pregnant non-Western women in The Hague, Netherlands. Am J Clin Nutr 84: 350-353. [Crossref]

66. Wagner CL, Taylor SN, Dawodu A, Johnson DD, Hollis BW (2012) Vitamin D and its role during pregnancy in attaining optimal health of mother and fetus. Nutrients 4 : 208-230. [Crossref]

67. McKenna M, Freaney R (1998) Secondary hyperparathyroidism in the elderly: means to defining hypovitaminosis D. Osteoporos Int 8: 3-6. [Crossref]

68. Carneiro Pedroza MA, Lazaretti Castro M (2005) Papel da Vitamina D na FunÃ §̃̃ £o Neuro-Muscular. Arq Bras Endocrinol Metab 49: 495-502.

69. Glerup H, Mikkelsen K, Poulsen L, Hass E, Overbeck S, et al. (2000) Hypovitaminosis D myopathy without biochemical signs of osteomalacic bone involvement. Calcif Tissue Int 66: 419-424. [Crossref]

70. Bhan A, Rao AD, Rao DS (2010) Osteomalacia as a result of vitamin D deficiency. Endocrinol Metab Clin North Am 39: 321-331. [Crossref]

71. Camacho PM, Petak SM, Binkley N, Clarke BL, Harris ST, et al. (2016) American Association of Clinical Endocrinologists and American College of Endocrinology Clinical Practice guidelines for the diagnosis and treatment of postmenopausal osteoporosis. Endocr Pract 22: 1-42. [Crossref]

72. Rossini M, Adami S, Bertoldo F, Diacinti D, Gatti D, et al. (2016) Guidelines for the diagnosis, prevention and management of osteoporosis. Reumatismo 68: 1-39. [Crossref]

73. Adami S, Giannini S, Bianchi G, Sinigaglia L, Di Munno O, et al. (2009) Vitamin D status and response to treatment in post-menopausal osteoporosis. Osteoporos Int 20: 239-244. [Crossref]

74. Lips P, Bouillon R, van Schoor NM, Vanderschueren D, Verschueren S, et al. (2010) Reducing fracture risk with calcium and vitamin D. Clin Endocrinol (Oxf) 73: 277-285. [Crossref]

75. Carmel AS, Shieh A, Bang H, Bockman RS (2012) The 25 (OH) D level needed to maintain a favorable bisphosphonate response is $\geq 33 \mathrm{ng} / \mathrm{ml}$. Osteoporos Int 23: 2479 2487. [Crossref]

76. Tripkovic L, Lambert H, Hart K, Smith CP, Bucca G, et al. (2012) Comparison of vitamin D2 and vitamin D3 supplementation in raising serum 25-hydroxyvitamin D status: a systematic review and meta-analysis. Am J Clin Nutr 95: 1357-1364. [Crossref]

77. Cannell JJ, Hollis BW, Zasloff M, Heaney RP (2008) Diagnosis and treatment of vitamin D deficiency. Expert Opin Pharmacother 9: 107-118. [Crossref]

78. Ramalho MJ, Coelho MAN, Pereira C (2017) Nanoparticles for Delivery of Vitamin D: Challenges and Opportunities. In: Gowder SA (ed) Critical Evaluation of Vitamin D. Clinical Evaluation. Croatia: InTech. pp 31-249.

79. Schacht E (2008) Reduction of falls and osteoporotic fractures: Plain vitamin D or D-hormone analogs? Geriatr Gerontol Int 8: 16-25.

80. Gupta K, Warner JT (2011) Inappropriate and inconsistent modalities of treatment of vitamin D deficiency in children. Arch Dis Child 96: 787. [Crossref]

81. Brandi L (2017) Alfacalcidol in CKD-MBD: A Fresh Look. J Clin Nephrol Res 4 1061-1067.

82. Leventis P, Patel S (2008) Clinical aspects of vitamin D in the management of rheumatoid arthritis. Rheumatology 47: 1617-1621. [Crossref]

83. Ketteler M, Block GA, Evenepoel P, Fukagawa M, Herzog CA, et al. (2017) Executive summary of the 2017 KDIGO Chronic Kidney Disease-Mineral and Bone Disorder (CKD-MBD) Guideline Update: what's changed and why it matters. Kidney Int 92: 26-36. [Crossref]

84. Armas LA, Hollis BW, Heaney RP (2004) Vitamin D2 is much less effective than vitamin D3 in humans. J Clin Endocrinol Metab 89: 5387-5391. [Crossref]

85. Hess AF, Lewis JM, Rivkin H (1930) Newer aspects of the therapeutics of viosterol (irradiated ergosterol). JAMA 94: 1885 .

86. Trang HM, Cole DE, Rubin LA, Pierratos A, Siu S, et al. (1998) Evidence that vitamin D3 increases serum 25-hydroxyvitamin D more efficiently than does vitamin D2. Am J Clin Nutr 68: 854-858. [Crossref]

87. Mastaglia SR, Mautalen CA, Parisi MS, Oliveri B (2006) Vitamin D2 dose required to rapidly increase 25OHD levels in osteoporotic women. Eur J Clin Nutr 60: 681-687. [Crossref]

88. Houghton LA, Vieth R (2006) The case against ergocalciferol (vitamin D2) as a vitamin supplement. Am J Clin Nutr 84: 694-697. [Crossref] 
89. Romagnoli E, Mascia ML, Cipriani C, Fassino V, Mazzei F, et al. (2008) Short and long-term variations in serum calciotropic hormones after a single very large dose of ergocalciferol (vitamin D2) or cholecalciferol (Vitamin D3) in the elderly. $J$ Clin Endocrinol Metab 93: 3015-3020. [Crossref]

90. Diez-Perez A, Naylor KE, Abrahamsen B, Agnusdei D, Brandi ML, et al. (2017) International osteoporosis foundation and european calcified tissue society working group. Recommendations for the screening of adherence to oral bisphosphonates. Osteoporos Int 28: 767-774. [Crossref]

91. Dawson-Hughes B, Heaney RP, Holick MF, Lips P, Meunier PJ, et al. (2004) Vitamin D round table. In: P. Burckhardt, B. Dawson-Hughes, R.P. Heaney (Eds) Nutritional Aspects of Osteoporosis, 2nd Edn, Elsevier Inc., San Diego pp. 263-270.

92. Holick MF (2017) The vitamin D deficiency pandemic: approaches for diagnosis, treatment and prevention. Rev Endocr Metab Disord 18: 153-165. [Crossref]

93. Thomas MK, Lloyd-Jones DM, Thadhani RI, Shaw AC, Deraska DJ, et al. (1998) Hypovitaminosis D in medical inpatients. $N$ Engl J Med 338: 777-783. [Crossref]

94. Heaney RP, Dowell MS, Hale CA, Bendich A (2003) Calcium absorption varies within the reference range for serum 25-hydroxyvitamin D. J Am Coll Nutr 22: 142-146. [Crossref]

95. Holick MF, Siris ES, Binkley N, Beard MK, Khan A, et al. (2005) Prevalence of vitamin D inadequacy among postmenopausal North American women receiving osteoporosis therapy. J Clin Endocrinol Metab 90: 3215-3224. [Crossref]

96. Dawson-Hughes B, Heaney RP, Holick MF, Lips P, Meunier PJ, et al. (2005) Estimates of optimal vitamin D status. Osteoporos Int 16: 713-716. [Crossref]

97. Talwar SA, Aloia JF, Pollack S, Yeh JK (2007) Dose response to vitamin D supplementation among postmenopausal African American women. Am J Clin Nutr 86: 1657-1662. [Crossref]

98. Binkley N, Gemar D, Engelke J, Gangnon R, Ramamurthy R, et al. (2011) Evaluation of ergocalciferol or cholecalciferol dosing, 1,600 IU daily or 50,000 IU monthly in older adults. J Clin Endocrinol Metab 96: 981-988. [Crossref]
99. Cesareo R, Attanasio R, Caputo M, Castello R, Chiodini I, et al. (2018) Italian Association of Clinical Endocrinologists (AME) and Italian chapter of the American Association of Clinical Endocrinologists (AACE) position statement: clinical management of vitamin D deficiency in adults. Nutrients 10: 546. [Crossref]

100. Veugelers P, Pham TM, Ekwaru J (2015) Optimal vitamin D supplementation doses that minimize the risk for both low and high serum 25-hydroxyvitamin D concentrations in the general population. Nutrients 7: 10189-10208. [Crossref]

101. Rizzoli R, Boonen S, Brandi ML, Bruyère O, Cooper C, et al. (2013) Vitamin D supplementation in elderly or postmenopausal women: a 2013 update of the 2008 recommendations from the European Society for Clinical and Economic Aspects of Osteoporosis and Osteoarthritis (ESCEO). Curr Med Res Opin 29: 305-313. [Crossref]

102. Vieth R (2013) The Pharmacology of Vitamin D, Including Fortification Strategies. In: Feldman D, Glorieux F (eds) Vitamin D, 2nd Edition. USA: Elsevier Academic Press pp 1041-1066.

103. Pludowski P, Karczmarewicz E, Bayer M, Carter G, Chlebna-Sokół D, et al (2013) Practical guidelines for the supplementation of vitamin $\mathrm{D}$ and the treatment of deficits in Central Europe-recommended vitamin D intakes in the general population and groups at risk of vitamin D deficiency. Endokrynol Pol 64: 319-327. [Crossref]

104. Briot K, Roux C, Thomas T, Blain H, Buchon D, et al (2018) 2018 update of French recommendations on the management of postmenopausal osteoporosis. Joint Bone Spine 85: 519-530. [Crossref]

105. Souberbielle JC, Cormier C, Cavalier E, Breuil V, Debiais F, et al. (2020) Vitamin D Supplementation in France in patients with or at risk for osteoporosis: Recent data and new practices. Joint Bone Spine 87: 25-29. [Crossref]

106. Pérez-López FR, Brincat M, Erel CT, Tremollieres F, Gambacciani M, et al. (2012) EMAS position statement: vitamin D and postmenopausal health. Maturitas 71: 8388. [Crossref]

107. Al-Daghri NM, Al-Saleh Y, Aljohani N, Sulimani R, Al-Othman AM, et al. (2017) Vitamin D status correction in Saudi Arabia: an expertsâ $€^{\mathrm{TM}}$ consensus under the auspices of the European Society for Clinical and Economic Aspects of Osteoporosis, Osteoarthritis, and Musculoskeletal Diseases (ESCEO). Arch Osteoporos 12: 1. [Crossref]

Copyright: (C2020 Vidal M. This is an open-access article distributed under the terms of the Creative Commons Attribution License, which permits unrestricted use, distribution, and reproduction in any medium, provided the original author and source are credited. 